Jolanta Kępa-Mętrak

Uniwersytet Jana Kochanowskiego w Kielcach

ORCID: 0000-0002-8368-5134

jolanta.kepa@ujk.edu.pl

\title{
CZY ZMIANY W FUNKCIONOWANIU PRASY LOKALNEJ SĄ KONIECZNE? DYSKUSJA WOKÓŁ MODELI PRASY SAMORZĄDOWEJ I PRYWATNEJ
}

\author{
Abstract \\ ARE CHANGES IN THE FUNCTIONING OF THE LOCAL PRESS NECESSARY? \\ DISCUSSION CONCERNING SELF-GOVERNMENT AND PRIVATE PRESS \\ MODELS
}

The aim of the article is to draw attention to the strength of the local press, a bit paradoxically, by recalling the examples of the activities taken by various bodies against local government press. I assume that if the strength of the local press in influencing on the communities of communes or poviats were not noticed, there would not be any initiatives to defend the so-called independent press, the initiatives which tried to ban the issuing of press by commune, poviat and voivodship self-governments. I compared the analysis of speeches of the Association of Local Newspapers, of the Ombudsman, of the Helsinki Foundation for Human Rights and finally of the Kukiz'15 parliamentary club with the latest data of the National Library concerning regional and local magazines which were registered in 2019. It turned out that they constitute nearly half of all new or changing titles submitted to the National Library. Among them there was 50 percent of magazines published by local governments or institutions subordinated to them. The existing projects aimed against self-government publishing activities have not been successful so far. The strength of the local press should not result from the status of its publisher, but from the message that the recipient gets.

Key words: local communication, local media, local press, local government press, media strength 


\section{Wstęp}

Komunikowanie w społecznościach lokalnych w znacznym stopniu opiera się na kontaktach interpersonalnych, co nie oznacza, że media odgrywają w nim rolę mało znaczącą. Od początku lat dziewięćdziesiątych badacze udowadniają, że media zajmują ważne miejsce w lokalnym systemie społecznym, politycznym, ekonomicznym, kulturowym. Szczególne zadania przypadały początkowo prasie, bo to ona najszybciej i najpełniej opanowała lokalne rynki. Z czasem ulegało to zmianie, głównie pod wpływem coraz powszechniejszego Internetu. Witryny i portale internetowe najpierw uzupełniały przekaz drukowany, później zaczęły go zastępować. Prasa jednak pozostała. Uległa przeobrażeniom, aby dostosować się do nowych warunków, ale nie zniknęła.

Jedna z podstawowych definicji prasy lokalnej mówi, że to

(...) bardzo niejednolita grupa wytworów prasowych, których wspólną cechą jest fakt ukazywania się poza głównym centrum lub głównymi ośrodkami życia polityczno-społecznego oraz kulturalnego danego kraju i kolportowania ich na określonym (zwykle granicami wewnętrznego podziału administracyjnego) terytorium ${ }^{1}$.

Nie można jednak w tak prosty, wręcz trywialny sposób oddać istoty prasy lokalnej. Ryszard Kowalczyk twierdzi, że próba zdefiniowania pojęcia prasa lokalna jest zabiegiem trudniejszym od „opisania fenomenu przez nie oznaczanego”, i jako dowód przytacza kilkanaście definicji różnych autorów, którzy na potrzeby własnej charakterystyki tejże różnie wyjaśniali znaczenie samego pojęcia ${ }^{2}$. Wskazując na łączenie w praktyce polskiej mediów lokalnych z podziałem terytorialnym i administracyjnym, zalicza do nich media dzielnicowe, osiedlowe, wiejskie, miejskie, gminne, powiatowe i wojewódzkie. Według innego podziału, który utożsamia media lokalne z nieogólnokrajowymi, wymienia media regionalne, podregionalne lub subregionalne, mikroregionalne, lokalne, sublokalne. Zwraca uwagę, że „według niektórych opinii kontrowersyjnym jest zaliczenie do mediów lokalnych tych inicjatyw prasowo-wydawniczych, które mają zasięg regionalny (wojewódzki) czy subregionalny (podregionalny)"”. Twierdzi jednak, że warto badać cały rynek mediów w ramach województwa, uwzględniając „także te media, które mają zasięg wykraczający poza obszar jednego czy kilku sąsiednich powiatów", a stanowisko takie potwierdza „argument o stopniowalności lokalności”. Podzielam to stanowisko. Dodatkowym uzasadnieniem dla jego przyjęcia jest analizowana prasa samorządowa, co do której nie ma wątpliwości, iż zalicza się do lokalnej, chociaż jest wydawana także przez urzędy marszałkowskie.

${ }^{1}$ Encyklopedia wiedzy o prasie, J. Maślanka (red.), Zakład Narodowy im. Ossolińskich, Wroclaw 1976, s. 174-175.

${ }^{2}$ R. Kowalczyk, Prasa lokalna w systemie komunikowania społecznego, Instytut Nauk Politycznych i Dziennikarstwa Uniwersytetu im. Adama Mickiewicza, Poznań 2003, s. 48.

${ }^{3}$ R. Kowalczyk, O mediach lokalnych, regionie i regionalizmie, Silva Rerum, Poznań 2015, s. 58-59. 
Na gazety lokalne jako główne narzędzia komunikowania lokalnego zwracał uwagę już wiele lat temu Günter Kieslich ${ }^{4}$, podkreślając sferę społeczną komunikowania. Nurt polityczny pojawił się natomiast w pracach Otfrieda Jarrena i Mattiasa Kurpa ${ }^{5}$. Kurp stworzył model komunikowania samorządowego, w którym lokalne media pełnią funkcję pośrednika pomiędzy samorządem a daną społecznością, realizując funkcje socjalizacyjne, mobilizacyjne i aktywizujące, a przede wszystkim uczestniczą w wymianie myśli. Model ten wpisuje się w polskie realia.

Od lat zajmuję się badaniami prasy lokalnej, obserwując zmiany, jakim ona podlega. Ewoluuje jej forma, treść, a także funkcje, jakie pełni. Jeszcze przed upadkiem poprzedniego systemu zaczęła powstawać niezależna prasa, która niemal masowo pojawiła się w latach dziewięćdziesiątych XX wieku. Ale - jak się szybko okazało - obecność na rynku wielu tytułów była tylko chwilowa. Zmianom politycznym towarzyszyły bowiem ekonomiczne. Konkurencja i tzw. wolny rynek najskuteczniej weryfikowały inicjatywy niepoparte rzetelnymi rachunkami finansowymi. Niebagatelną rolę odegrała też reforma samorządowa. W kształtującym się na nowo rynku mediów lokalnych dało się wyraźnie zaobserwować podziały ze względu na charakter ich własności: prywatne i samorządowe. Powstałe wówczas antagonizmy pomiędzy wydawcami prywatnymi a samorządowymi pozostają niezmienne do dzisiaj.

Celem artykułu jest ukazanie najnowszego etapu dyskusji toczącej się wokół roli i kondycji prasy lokalnej, którą reprezentują dwie jej odmiany: samorządowa i prywatna. Określenie tej roli jest istotne nie tylko w aspekcie funkcjonowania samorządu czy społeczności lokalnej, ale także w perspektywie systemu medialnego. Uwagę badacza musi zwrócić podejmowanie ciągle nowych inicjatyw, zmierzających do wyeliminowania $\mathrm{z}$ rynku prasy samorządowej na rzecz prasy prywatnej. Rodzą się w związku z tym pytania: kim są przeciwnicy prasy samorządowej?, dlaczego występują przeciwko niej?, w czyjej obronie stają - odbiorców czy nadawców? Te pytania stały się inspiracją do próby określenia na nowo roli prasy lokalnej w procesie komunikacji, w powiązaniu z działaniami zmierzającymi do prawnej regulacji zasad jej wydawania. Analizie poddano dwa typy źródeł. Jedna grupa to przede wszystkim dokumenty urzędowe $\mathrm{z}$ lat $2015-2018 \mathrm{w}$ postaci petycji Helsińskiej Fundacji Praw Człowieka i Rzecznika Praw Obywatelskich w sprawie zagrożeń wynikających z wydawania prasy samorządowej wraz z odpowiedziami na nie oraz wypowiedzi wydawców prywatnych w tej kwestii. Druga grupa obejmuje dane dotyczące nowych tytułów prasy lokalnej dostępne w bazie czasopism polskich

${ }^{4}$ G. Kieslich, Lokale Kommunikation: ihr Stellenwert im Zeitgespräch der Gesellschaft, „Publizistik: Vierteljahreshefte für Kommunikationsforschung" 1972, Vol. 17, No. 1, s. 95-101.

${ }^{5}$ O. Jarren, Kommunale Kommunikation: Eine theoretische und empirische Untersuchung kommunaler Kommunikationsstrukturen unter besonderer Berücksichtigung lokaler und sublokaler Medien, Minerva Publikation, München 1984; M. Kurp, Lokale Medien und kommunale Eliten Partizipatorische Potentiale des Lokaljournalismus bei Printmedien und Hörfunk in Nordrhein-Westfalen, Westdeutscher Verlag, Opladen 1994. 
Biblioteki Narodowej za rok 2019. Skonfrontowanie danych z obydwu typów źródeł pozwala określić aktualną kondycję prasy lokalnej oraz podjąć próbę wnioskowania o jej przyszłości.

\section{Działalność wydawnicza samorządów jako element polityki lokalnej}

Prasa samorządowa pojawiła się wraz z powołaniem samorządów w 1990 roku, a właściwie zaistniała jeszcze przed ich formalnym utworzeniem. Do dzisiaj odnotowano kilka tysięcy tytułów, w tym wiele efemerycznych, w mniejszym lub większym stopniu odpowiadających definicjom prasy. Nie ma w Polsce województwa, a nawet powiatu, w których w ostatnim trzydziestoleciu nie wydawano by prasy samorządowej. Dziś, mimo zmiany kanałów komunikacyjnych, nadal bardzo wiele samorządów wydaje własne czasopisma. Istnieją periodyki samorządów gminnych, powiatowych, wojewódzkich. Jedne przygotowywane są profesjonalnie, inne amatorsko. Jedne posiadają określoną periodyczność, ukazują się regularnie co miesiąc, dwa, czasami częściej, inne wydawane są nieregularnie - trafiają do odbiorców sporadycznie: raz na kwartał lub rzadziej. Wszystkie łączy wspólny cel: mają dostarczać informacji o działalności lokalnych samorządów i zachęcać do angażowania się mieszkańców we wspólne sprawy.

Samo określenie prasa samorządowa jest różnie interpretowane przez medioznawców. Używane przeze mnie odnosi się do prasy wydawanej przez samorządy lokalne - nazwę uzasadnia instytucja sprawcza i/lub finansująca przedsięwzięcie ${ }^{6}$. Inne zdanie na ten temat ma np. Alicja Jaskiernia, dla której pojęcie to powinno odnosić się do prasy „organizacyjnie niezależnej” i samofinansującej się, wydawanej przez inne podmioty niż samorządy lokalne ${ }^{7}$. Stanowisko to nie upowszechniło się. Wydawcy prasy niezależnej natomiast wyraźnie odcinają się od prasy powszechnie nazywanej samorządową, tj. wydawanej przez samorządy.

Prasa prywatna zawsze była i jest w opozycji do prasy samorządowej. Prywatna także jest bardzo licznie reprezentowana na polskim rynku. Wydawcy podkreślają jej niezależność i realizowanie - poza funkcjami informacyjną, integracyjną czy mobilizacyjną - bardzo ważnej ze społecznego punktu widzenia funkcji kontrolnej, której pozbawiona jest prasa samorządowa. Czasopismom samorządowym często towarzyszy atmosfera niechęci, czy wręcz wrogości ze strony wydawców prywatnych. Nie są też przyjmowane dobrze przez niektórych medioznawców, parlamentarzystów. Niejedna dyskusja w różnych gremiach kończyła się twierdzeniami, że

${ }^{6}$ Por. m.in. J. Kępa-Mętrak, Relacje pomiędzy lokalną prasą prywatna a samorzadową na przykładzie województwa świętokrzyskiego, [w:] M. Lipińska (oprac.), Prasa lokalna w budowie społeczeństwa obywatelskiego, Warszawa 2005, s. 166.

7 A. Jaskiernia, Media masowe $w$ demokratycznych procesach wyborczych. Standardy europejskie i uwarunkowania ich realizacji, Oficyna Wydawnicza Aspra, Warszawa 2008, s. 56. 
wydawnictwa samorządowe są zagrożeniem dla wolności słowa i powinny zostać zlikwidowane. Już przed laty, podczas konferencji zorganizowanej przez Komisję Kultury i Środków Przekazu przy współudziale Izby Wydawców Prasy, przyjęto stanowisko negujące sens istnienia czasopism samorządowych ${ }^{8}$.

O wyodrębnieniu prasy wydawanej przez samorządy spośród innych jej typów decyduje sposób finansowania, tzn. utrzymywanie jej ze środków pochodzących z budżetu samorządów terytorialnych. Rolą samorządowej administracji gminnej i powiatowej powinno być pełnienie funkcji usługowych wobec społeczności lokalnych. Wśród wielu jej zadań wymienia się m.in. promocję oraz współpracę i działalność na rzecz organizacji pozarządowych ${ }^{9}$. W tych ostatnich zadaniach zmieścić by można działalność medialną, tj. tworzenie własnych publikatorów oraz wspieranie innych lokalnych środków przekazu. Ustawodawca zagwarantował, że gminy i powiaty mogą tworzyć jednostki odpowiedzialne za komunikację medialną lub zlecać takie zadania innym podmiotom. Podobnie mogą postępować w kwestii medialnej samorządy wojewódzkie ${ }^{10}$. Własne media mają pomagać w realizacji zadań przypisywanych poszczególnym jednostkom samorządu terytorialnego. Do najważniejszych ich funkcji należy szeroko rozumiana promocja „małej ojczyzny”, integracja społeczności lokalnych i ponadlokalnych, promowanie inicjatyw lokalnych. Można to osiągnąć poprzez informowanie o lokalnej rzeczywistości, ale w jeszcze większym stopniu przez jej wyjaśnianie, przekonywanie o słuszności podejmowanych działań, zachęcanie do angażowania się w nie, kształtowanie postaw, zachowań.

Działalność wydawnicza samorządów lokalnych jest zatem elementem całościowej polityki lokalnej, wynikającej z przyjętych zadań własnych gminy, w tym bezpośrednio realizowaniem zadań informacyjnych, podobnie jak publikowanie wiadomości w Biuletynie Informacji Publicznej, tyle że w postaci zmaterializowanej, rzeczowej. W periodykach czasem są publikowane pełne treści różnego typu dokumentów urzędowych lub ich skróty, omówienia. Na ich łamach zamieszczane są informacje o przygotowywanych aktach normatywnych, planowanych działaniach w różnych sferach życia społecznego, gospodarczego czy kulturalnego, przetargach na wykonanie różnorodnych prac itp. Niezmiernie istotne ze społecznego punktu widzenia są informacje dotyczące budżetu gminy, powiatu czy województwa. Znajduje się tam odniesienie także do posiedzeń organów kolegialnych jednostek samorządu terytorialnego, pochodzących z powszechnych wyborów (rad gminy, powiatu, sejmiku województwa), komisji rady. Bywają drukowane informacje dotyczące posiedzeń zarządów, choć tu zasada jawności stosowana jest w ograniczonym stopniu.

${ }^{8}$ M. Lipińska (oprac.), Prasa lokalna...

9 Ustawa z dnia 8 marca 1990 r. o samorządzie gminnym, Rozdział 2. Zakres działania i zadania gminy; Dz.U. 1990 Nr 16 poz. 95 z późn. zm.; Ustawa z dnia 5 czerwca 1998 r. o samorządzie powiatowym, Rozdział 2. Zakres działania i zadania powiatu; Dz.U. $1998 \mathrm{Nr} 91$ poz. 578 z późn. zm.

${ }_{10}$ Ustawa z dnia 5 czerwca 1998 r. o samorządzie województwa, Rozdział 2. Zakres działalności; Dz.U. 1998 Nr 91 poz. 576 z późn. zm. 
Analiza zawartości wybranych periodyków samorządowych $\mathrm{z}$ początku XXI wieku wskazywała, że duża część czasopism wydawanych i/lub finansowanych przez samorządy lokalne była ich tubą ${ }^{11}$. W treści przeważały sprawozdania z sesji, obrad zarządów, różnych imprez, uroczystości z udziałem wójtów, burmistrzów, starostów. Czasem sięgano do historii, popularyzowano walory turystyczne gmin, zachęcano mieszkańców do podejmowania konkretnych inicjatyw, np. $\mathrm{w}$ zakresie przeciwdziałania bezrobociu, zwalczania patologii. $\mathrm{W}$ rzeczywistości promowały jednak przeważnie tylko sprawujących władzę, ukazując ich zasługi dla lokalnej społeczności, czasem faktyczne, często pozorne, związane z obecnością $\mathrm{w}$ różnych miejscach. Późniejsze analizy pozwalały zauważyć, że w wielu pismach aktywność włodarzy gmin i powiatów nie była już tak wyraźnie eksponowana. Ich działalność ożywiała się zwykle w okresie przedwyborczym. Oczywiste jest, że dotychczasowi wójtowie, burmistrzowie, starostowie chcieli zaprezentować swoje dokonania, pokazać, że dotrzymują obietnic składanych mieszkańcom. Duża część z nich robiła to bardzo skutecznie, o czym świadczą wygrane na kolejne kadencje wybory.

Za największą wadę prasy samorządowej uznaje się brak obiektywizmu, wynikający z przedstawiania problemów głównie z perspektywy władzy. Przeważnie mamy w niej do czynienia $z$ informacją pochodzącą bezpośrednio od urzędników, czyli ze źródła, które je wytwarza. Brak konfrontacji z innymi źródłami jest oczywistym błędem w sztuce dziennikarskiej. Jeśli jednak potraktujemy gminne gazety jako uzupełnienie czy rozszerzenie elektronicznego Biuletynu Informacji Publicznej, to wówczas rozpatrywanie ich zawartości z punktu widzenia przekazu dziennikarskiego nie znajduje uzasadnienia. Dobrze redagowany informator, zawierający najważniejsze $\mathrm{w}$ danej chwili wiadomości o pracy urzędu i podległych mu placówek, to realizacja cząstki zadań przypisanych gminie. Pamiętać jednak należy, że wydawanie periodyków przez samorządy to nie tylko informowanie społeczeństwa o działaniach władz, lecz także przekonywanie o ich słuszności.

\section{Stanowisko wydawców prywatnych wobec prasy samorządowej}

Relacje pomiędzy prasą prywatną i samorządową były już przedmiotem niejednej dyskusji (sprawa nie jest bowiem jednoznaczna), a jej podejmowanie wyraźnie potwierdza siłę oddziaływania mediów w lokalnych środowiskach. Pierwsze gorące dyskusje na ten temat pojawiały się już na przełomie wieków. Ale żeby nie sięgać tak daleko, zwróćmy uwagę tylko na ostatnie lata. Wydawcy gazet prywatnych podkreślają zagrożenie ze strony samorządów przy każdej okazji. Na początku stycznia

${ }^{11}$ J. Kępa-Mętrak, Prasa samorządowa w procesie komunikowania władzy ze społeczeństwem, [w:] J. Kowalik, A. Bednarz (red.), XX lat samorządu terytorialnego w Polsce. Doświadczenia - problemy-perspektywy, Wydawnictwo Adam Marszałek, Toruń 2011, s. 295-316. 
2015 roku, zabierając głos w dyskusji o repolonizacji mediów, portal money.pl dokonał przeglądu własnościowego czołowych stacji telewizyjnych, dzienników, tygodników, portali i rozgłośni radiowych ${ }^{12}$. Dwa tygodnie później, powołując się na czytelników, którzy domagali się uwzględnienia w nim prasy lokalnej, opublikowano kolejne zestawienie, łącząc prasę regionalną z lokalną ${ }^{13}$. Wywołało to natychmiastowe reakcje wydawców lokalnych na temat „medialnych doniesień, że wszystkie gazety lokalne są niemieckie, bo tak czasami piszą niektórzy, nie odróżniając dzienników regionalnych od gazet lokalnych"14. Ryszard Pajura, redaktor naczelny i wydawca "Obserwatora Lokalnego" z Dębicy, twierdził wówczas, że „prasa lokalna to praktycznie w 100 procentach nie tylko kapitał rodzimy, ale mały, ulokowany w lokalnych środowiskach". Wtórowała mu Alicja Molenda, prezes Rady Wydawców Stowarzyszenia Gazet Lokalnych (SGL), wydawca tygodnika ziemi chrzanowskiej „Przełom”. Nie ten problem uznała jednak za najważniejszy:

O kwestiach własnościowych na rynku medialnym przypominaliśmy przy każdej okazji. Temat zawsze jednak umierał śmiercią naturalną, bo w jakiś sposób mieścił się w granicach prawa. Od lat nikt też specjalnie nie chce wsłuchać się w nasze głosy dotyczące potężnej rynkowej konkurencji, jaką są dla nas media samorządowe, wydawane wbrew ustawowej zasadzie subsydiarności lokalnych organów władzy wobec przedsiębiorców. To one wkraczają na rynek reklamowy, burzą też obraz niezależności mediów na poziomie lokalnym, co w wielu wypadkach uderza w niezależnych wydawców. Po prostu jesteśmy z prasą samorządową myleni. W tej sprawie nie składamy jednak broni ${ }^{15}$.

Zapowiedziana walka została wznowiona w roku 2016. Wydawcom prywatnym udało się wówczas zainteresować problemem Rzecznika Praw Obywatelskich (RPO). 11 maja 2016 roku Helsińska Fundacja Praw Człowieka (HFPC) skierowała do rzecznika petycję w sprawie ograniczenia działalności wydawniczej samorządów, nazywając ją „jednym z najpoważniejszych zagrożeń dla wolności słowa na poziomie lokalnym”. Podstawą petycji stał się artykuł Wydawanie gazet przez jednostki samorzadu terytorialnego - wątpliwości konstytucyjne, opublikowany w roku 2014 na łamach „Samorządu Terytorialnego" ${ }^{16}$, którego obszerne fragmenty bezpośrednio przytoczono. Podkreślono w niej szczególną rolę prasy lokalnej wśród mediów, zwracając uwagę na jej funkcję kontrolną wobec samorządu oraz zagrożenia dla jej istnienia ze strony władz:

12 Zob. https://www.money.pl/gospodarka/wiadomosci/artykul/media-w-polsce-do-kogo-nalezy-prasa-,138,0,1988746.html (dostęp: 3.09.2019).

${ }_{13}$ Zob. https://www.money.pl/gospodarka/wiadomosci/artykul/media-w-polsce-do-kogo-naleza-gazety-lokalne,217,0,1996761.html (dostęp: 3.09.2019).

${ }_{14}$ Zob. http://gazetylokalne.pl/slyszalam-ze-sprzedales-gazete-niemcom/ (dostęp: 3.09.2019).

15 Tamże.

16 D. Głowacka, A. Ploszka, Wydawanie gazet przez jednostki samorzadu terytorialnego - wątpliwości konstytucyjne, „Samorząd Terytorialny” 2014, nr 11, s. 75-83; dostępny także online: https:// www.prawo.pl/samorzad/czy-samorzady-powinny-wydawac-gazety,99432.html (dostęp: 3.09.2019). 
W związku z pełnieniem tej funkcji media są nazywane „publicznym stróżem” (Public Watchdog). (...) W odniesieniu do mediów lokalnych funkcja watchdoga jest szczególnie ważna, gdyż często stanowi jedyny mechanizm kontroli samorządowych urzędników. Aby jednak niezależna prasa lokalna mogła właściwie wypełniać przypisane jej zadania, w szczególności ową funkcję społecznej kontroli administracji, nie może napotykać na przeszkody w działalności ze strony władzy samorządowej. Za taką przeszkodę HFPC uznaje wydawanie gazet przez JST bądź podległe im instytucje ${ }^{17}$.

Kolejne fragmenty odnoszą się do prasy wydawanej przez samorządy i wskazują na jej negatywny wpływ na odbiorców, pozbawionych „rzetelnej, niezależnej informacji (...) poprzez uniemożliwienie prezentowania na łamach gazety samorządowej poglądów krytycznych w stosunku do władzy ją wydającej”, oraz na potencjalnych wydawców niezależnych „poprzez uniemożliwienie lub utrudnienie wejścia na rynek prasie prywatnej”. Uwzględniają także uwarunkowania prawne. Konkluzja jest następująca:

Uznanie zgodności z prawem wydawania gazet samorządowych pozostaje w interesie JST, dla których korzystne jest posiadanie medium stanowiącego cenny instrument perswazji, a nawet walki politycznej, w szczególności w niewielkich gminach, gdzie taka gazeta stanowi jedyne medium na rynku. Z kolei dla członków danej wspólnoty samorządowej taka gazeta często stanowić będzie zagrożenie dla korzystania przez nich z podstawowych praw i wolności ${ }^{18}$.

Informacja o petycji HFPC znalazła się następnego dnia na stronie Obserwatorium Wolności Mediów w Polsce. Komentował ją Adam Ploszka, prawnik HFPC, współautor przywołanego wyżej artykułu ${ }^{19}$.

\section{Interwencje Rzecznika Praw Obywatelskich}

Zastanawiające jest, że dwa dni wcześniej RPO Adam Bodnar skierował pismo do Ministra Spraw Wewnętrznych i Administracji (MSWiA) Mariusza Błaszczaka w związku ze skargami „od obywateli wydających lokalne tytuły prasowe, w których zwrócono uwagę na negatywne skutki wynikające $\mathrm{z}$ wydawania prasy przez władze jednostek samorządów terytorialnych" ${ }^{20}$. Argumenty były takie same jak w petycji

17 Zob. https://www.hfhr.pl/wp-content/uploads/2016/05/petycja_HFPC_gazety_samorzadowe.pdf (dostęp: 3.09.2019).

18 Tamże.

19 Zob. http://www.obserwatorium.org/index.php?option=com_content\&view=article \&id=4817:czy-wydawanie-gazet-samorzdowych-jest-zgodne-z-konstytucj-petycja-do-rpo\&catid=47: aktualnosciprog\&Itemid=66 (dostęp: 3.09 .2019 ).

20 Zob. https://www.rpo.gov.pl/pl/content/wystapienie-do-ministra-spraw-wewnetrznychi-administracji-ws-wydawania-prasy-przez-wladze; https:/www.rpo.gov.pl/sites/default/files/Wystapienie\%20do\%20Ministra\%20Spraw\%20Wewnętrznych\%20i\%20Administracji\%20ws\%20wydawania\%20prasy\%20przez\%20wladze\%20samorzadowe\%2009.05.2016.pdf (dostęp: 3.04.2019). 
HFPC i też w znacznym stopniu zaczerpnięte $\mathrm{z}$ artykułu prawnika fundacji, Adama Ploszki. Minister, wbrew sugestii zawartej w tytule informacji opublikowanej 14 czerwca 2016 roku na oficjalnej stronie RPO Wydawanie prasy przez władze samorządowe - minister podziela wątpliwości RPO, przyznał jedynie, że „celowe wydaje się zaangażowanie w dyskusję szerszego kręgu podmiotów”, wskazując Ministra Kultury i Dziedzictwa Narodowego (MKiDN), „który pozostaje właściwy w zakresie wprowadzenia ewentualnych zmian w ustawie - Prawo prasowe" oraz Urząd Ochrony Konkurencji i Konsumentów „w zakresie ograniczenia konkurencji przez działalność wydawniczą jednostek samorządu terytorialnego" ${ }^{21}$. Identyczne wystąpienia do obydwu podmiotów zostały skierowane na początku lipca 2016 roku $^{22}$.

Wystąpienie RPO do MSWiA z dnia 9 maja 2016 roku odbiło się szerokim echem w mediach. Pisały o nim m.in.: PAP w serwisie samorządowym, „Puls Biznesu”, „Gazeta Wyborcza”, portal Sieć Obywatelska, Portal Samorządowy i oczywiście SGL ${ }^{23}$. Sprawa miała ciąg dalszy. Kolejne wystąpienia RPO pozostawały jednak bez konkretnych rezultatów. 25 kwietnia 2018 roku rzecznik ponownie zwrócił się do MKiDN w sprawie wydawania prasy przez władze samorządowe, podkreślając „negatywne skutki wynikające $z$ wydawania prasy przez władze jednostek samorządów terytorialnych, w tym zagrożenia związane z tym zjawiskiem dotyczące naruszenia swobody wypowiedzi”24. Przypomniał równocześnie, że podejmował ten temat już czterokrotnie w wystąpieniach z 6 lipca i 15 listopada 2016 roku oraz 27 lutego i 11 września 2017 roku, powielając ich obszerne fragmenty ${ }^{25}$. Zwracając uwagę na brak reakcji rządu, podkreślał, że:

(...) kwestia wydawania prasy lokalnej przez władze jednostek samorządu terytorialnego nie została do chwili obecnej poddana powszechnej i pogłębionej analizie, a regulacje prawne w tym zakresie nie uległy zmianie. W konsekwencji regulacje prawne odnoszące się do zagadnień budzących wskazane powyżej wątpliwości konstytucyjne nadal pozostają w polskim porządku prawnym i w dalszym ciągu wywołują negatywne dla obywateli skutki.

${ }^{21}$ Zob. https://www.rpo.gov.pl/pl/content/wydawanie-prasy-przez-wladze-samorzadowe-minister-podziela-watpliwosci-rpo; https://www.rpo.gov.pl/sites/default/files/Odp\%20MSWiA\%20 prasa\%20samorzadowa\%2002.06.2016.pdf (dostęp: 4.09.2019).

${ }_{22}$ Zob. https://www.rpo.gov.pl/sites/default/files/Wystapienie\%20do\%20Ministra\%20Spraw\%20 Wewnętrznych...

${ }_{23}$ Zob. http://samorzad.pap.pl/depesze/wiadomosci_centralne/164324/; https://www. pb.pl/bodnar-o-samorzadowych-gazetach-830808; http://wyborcza.pl/1,75398,20064763,rpo-do-szefa-mswia-wladza-lokalna-nie-powinna-wydawac-gazet.html; https://siecobywatelska.pl/ gminne-gazety-wladzy/; https://www.portalsamorzadowy.pl/komunikacja-spoleczna/gminyi-powiaty-nie-powinny-wydawac-prasy-tylko-biuletyny,80542.html; http://gazetylokalne.pl/rzecznik-praw-obywatelskich-w-sprawie-prasy-samorzadowej/ (dostęp: 3.09.2019).

${ }^{24}$ Zob. https://www.rpo.gov.pl/pl/content/rpo-samorzady-nie-powinny-wydawac-prasy-jedynie-biuletyny-informacyjne (dostęp: 4.09.2019).

${ }_{25}$ Zob. https://www.rpo.gov.pl/sites/default/files/Wyst\%C4\%85pienie\%20RPO\%20do\%20 MKiDN\%20w\%20sprawie\%20wydawania\%20prasy\%20przez\%20w\%C5\%82adze\%20samorz\% C4\%85du\%20terytorialnego.pdf (dostęp: 4.09.2019). 


\section{Projekt nowelizacji prawa prasowego}

16 lutego 2017 roku HFPC zwróciła się do Sejmowej Komisji Kultury i Środków Masowego Przekazu z wnioskiem o podjęcie prac nad zmianą ustawy „eliminującej możliwość wydawania prasy przez samorządy”. Odpowiedź wiceprzewodniczącego Sejmowej Komisji Kultury, wskazująca, że temat zostanie podjęty, nadeszła po czterech miesiącach ${ }^{26}$. Sprawa wróciła pod koniec roku 2018 w związku z projektem nowelizacji prawa prasowego, złożonym przez klub poselski Kukiz'15.

10 października 2018 roku klub poselski Kukiz'15 złożył projekt ustawy zmieniającej zapisy prawa prasowego dotyczące wydawców prasy. Art. 8 ust. 1 ustawy Prawo prasowe miałby brzmieć:

Wydawcą może być osoba prawna, fizyczna lub inna jednostka organizacyjna, choćby nie posiadała osobowości prawnej. W szczególności wydawcą może być organ państwowy, przedsiębiorstwo państwowe, organizacja polityczna, związek zawodowy, organizacja spółdzielcza, inna organizacja społeczna oraz kościół i inny związek wyznaniowy. Wydawcą nie może być gmina, powiat lub województwo ${ }^{27}$.

Zmiany wymagałyby także nowelizacji ustaw: z dnia 8 marca 1990 roku - o samorządzie gminnym, z dnia 5 czerwca 1998 roku - o samorządzie powiatowym, a także z dnia 5 czerwca 1998 roku - o samorządzie województwa. Projektem żywo zainteresowało się SGL, zrzeszające wydawców prywatnych. 22 listopada 2018 roku odbyło się spotkanie przedstawicieli SGL i dyrektora Izby Wydawców Prasy Marka Frąckowiaka z posłami Ruchu Kukiz'15 (m.in. wicemarszałkiem sejmu Stanisławem Tyszką). Zaproponowano rozszerzenie zakazu wydawania prasy o jednostki organizacyjne samorządu i spółki komunalne ${ }^{28}$.

26 listopada 2018 roku HFPC zamieściła na swojej stronie Uwagi do projektu ustawy o zmianie ustawy prawo prasowe oraz niektórych innych ustaw. Według niej przepis o wprowadzeniu bezpośredniego zakazu wydawania prasy przez samorządy gminne, powiatowe czy wojewódzkie „stanowi odpowiedź i próbę wyeliminowania jednego z najpoważniejszych zagrożeń dla wolności słowa na poziomie lokalnym, jakim jest praktyka wydawania przez jednostki samorządu terytorialnego tytułów prasowych". HFPC zwróciła się więc do Marszałka Sejmu z wnioskiem o skierowanie projektu do dalszych prac, wskazując równocześnie, że „zakaz wydawania prasy powinien obejmować nie tylko jednostki samorządu terytorialnego, lecz również jednostki budżetowo im podległe (np. domy kultury) oraz przedsiębiorstwa $\mathrm{z}$ udziałem gminy, powiatu lub województwa"29.

${ }^{26}$ Zob. https://www.hfhr.pl/uwagi-hfpc-do-projektu-ustawy-o-zmianie-ustawy-prawo-prasowe-oraz-niektorych-innych-ustaw/ (dostęp: 4.09.2019).

27 Zob. http://orka.sejm.gov.pl/Druki8ka.nsf/Projekty/8-020-1123-2018/\%24file/8-020-1123-2018.pdf (dostęp: 4.09.2019).

${ }_{28}$ Zob. http://gazetylokalne.pl/gminy-nie-powinny-wydawac-gazet/ (dostęp: 4.09.2019).

29 Zob. https://www.hfhr.pl/uwagi-hfpc-do-projektu-ustawy-o-zmianie-ustawy-prawo-prasowe-oraz-niektorych-innych-ustaw/ (dostęp: 4.09.2019). 
Ustawa, według projektodawców, miała wejść w życie z dniem 1 stycznia 2019 roku. Nie weszła. Spodziewać się jednak należy, że kwestia zakazu wydawania prasy samorządowej będzie powracać.

\section{Siła prasy lokalnej}

Gdyby nie dostrzegano siły prasy lokalnej i jej roli w komunikowaniu na poziomie gmin czy powiatów, nie byłoby tyle inicjatyw podejmowanych w obronie prasy tzw. niezależnej, a przeciwko prasie samorządowej ${ }^{30}$. Działania wydawców prywatnych $\mathrm{w}$ tym zakresie wynikają $\mathrm{z}$ ich bezpośredniego interesu - w niektórych środowiskach wydawanie gazet przez samorządy może ograniczać możliwości ich rozwoju i mieć przełożenie na wyniki finansowe. Zastanawiające jest jednak zaangażowanie HFPC i RPO. W ich kolejnych wystąpieniach argumenty dotyczące wolności słowa i prawa dostępu do informacji przez obywateli mieszają się z troską o wydawców prywatnych, dla których prasa samorządowa jest konkurencją. Równocześnie wydawcy zrzeszeni w SGL, zwracający uwagę, że działalność wydawnicza samorządów ogranicza wydawanie prasy prywatnej, w latach 2010-2015 odnotowali co najmniej 9 nowych projektów członków SGL, polegających na powołaniu nowych tytułów lub poszerzeniu zasięgu sprzedaży ${ }^{31}$.

4 lutego 2010 roku „Gazeta Lokalna Kutna i Regionu” poszerzyła zasięg sprzedaży o powiaty łęczycki i gostyniński. W tym samym roku „Głos Siemiatycz” zmienił nazwę na „Kurier Podlaski - Głos Siemiatycz” i zaczął ukazywać się na terenie kolejnych powiatów, m.in. bielskiego. W 2011 roku ukazał się pierwszy numer „Tygodnika Człuchowskiego”, którego wydawcą była firma Magraf, należąca do Macieja Grzmiela. 8 lutego 2013 roku w Tarnowie powstał „Tygodnik Miasto i Ludzie”, a w czerwcu Mateusz Orzechowski utworzył tygodnik „Wspólnota Puławska”. Także w tym roku „Nowej Gazecie Lokalnej” przybył „młodszy brat” - bezpłatny miesięcznik „Flesz Kędzierzyńsko-Kozielski”. W styczniu 2015 roku ukazała się „Korso - Gazeta Sanocka”, określana jako pierwsza niezależna gazeta w powiecie sanockim, w październiku Wydawnictwo Starpress ze Starachowic wydało swój nowy tygodnik w powiecie opoczyńskim - „Opoczyńska.pl”,

${ }^{30}$ Siła mediów, zgodnie z definicją T. Gobana-Klasa, polega na osiąganiu założonego przez nadawcę celu komunikacyjnego. Poglądy dotyczące siły mediów ulegały ewolucji. Nie jest stała także siła mediów. S. Ball-Rokeach zwracał uwagę na jej zależność od kontekstu społecznego: rośnie w czasach niepewności, kryzysów, zagrożenia ładu społecznego. Wprawdzie - jak twierdzą J. Eldridge, J. Kitzinger i K. Williams - ludzie różnie odbierają i interpretują przekazy, jednak media kształtują percepcję społeczną, a nieuważne korzystanie z nich może jeszcze wzmacniać ich moc. Por. T. Goban-Klas, Media i komunikowanie masowe. Teorie i analizy prasy, radia, telewizji i Internetu, Wydawnictwo Naukowe PWN, Warszawa-Kraków 1999, s. 236-273.

${ }^{31}$ Zob. http://gazetylokalne.pl/dwudziestopieciolatkow-pietnastu/ (dostęp: 4.09.2019). 
a w listopadzie powstał kolejny tygodnik Mateusza Orzechowskiego - „Wspólnota Łęczyńska"32.

Decyzja o powołaniu nowych periodyków samorządowych należy do wójta/ burmistrza lub rady gminy na najniższym poziomie władzy lokalnej bądź ich odpowiedników na poziomach wyższych - starosty, rady powiatu, marszałka, sejmiku. Powstawaniu nowych pism sprzyjają wybory samorządowe. Nowe tytuły pojawiają się przed rozpoczęciem kampanii wyborczej jako podsumowanie kadencji, ukazanej przez pryzmat sukcesów władzy. Jeśli władza się zmienia, także działalność wydawnicza może ulec zmianie. Bywa, że dotychczasowe tytuły są zawieszane, a zamiast nich powołuje się nowe lub kończy się działalność wydawniczą. Bywa, że zachowana jest ciągłość tytułu, ale następuje wewnętrzna reorganizacja i zmiana charakteru pisma, czasem jego częstotliwości.

Na początku lat dziewięćdziesiątych tylko na podstawie autopsji można było odtworzyć stan liczbowy prasy lokalnej i zmiany w nim zachodzące. Rejestry sądowe zawierały informacje o niewielkiej części periodyków. Jeszcze mniej powszechnym zjawiskiem było ich zgłaszanie do Biblioteki Narodowej i nadawanie numerów ISSN. Nie w pełni odzwierciedlał stan faktyczny także Katalog Mediów Polskich. Stąd brak precyzji w określaniu ilościowym periodyków. Problem ten zresztą występuje do dzisiaj.

\section{Statystyka Biblioteki Narodowej}

W bazie czasopism Biblioteki Narodowej (BN) za rok 2019 (pierwsze i ostatnie numery tytułów zarejestrowanych do 10 września 2019 roku) pojawiło się 109 dokumentów, wśród nich 41 w kategorii „czasopismo regionalno-lokalne” (jeden się powtarzał, więc czasopism było 108 ogółem, 40 regionalno-lokalnych) ${ }^{33}$. Podział na czasopisma wydawane przez samorządy i inne podmioty okazał się równomierny (wykres 1).

16 tytułów wydają bezpośrednio samorządy, w tym 5 urzędy miast (Lędziny, Łomianki, Kielce, Krynica-Zdrój i Włocławek), 9 gminy (Dzierżoniów, Łęki Szlacheckie, Dobrzyniewo Duże, Kęsowo, Domaszowice, Somonino, Łabunie, Kodeń i Czorsztyn), 1 powiat (Ciechanów) i 1 rada dzielnicy (Kraków Stare Miasto). 4 czasopisma należą do jednostek podległych samorządom: 2 ośrodki kultury (Nakło i Wielka Wieś), 1 spółka miejska (Wrocław) i 1 podległa starostwu powiatowemu galeria sztuki (Piła). Pozostałe należą do innych wydawców: 9 do

32 Zob. http://gazetylokalne.pl/wp-content/uploads/2015/12/Gazety_lokalne_w_Polsce_-_ kalendarium_z_obrazkiem_ver1.pdf (dostęp: 10.09.2019). SGL nie publikuje podobnych danych za kolejne lata.

${ }_{33}$ Zob. http://mak.bn.org.pl/cgi-bin/makwww.exe?BM=24\&IM=07\&WI=2019\&NU=01\&CE= 10\&MA1=rozwi\%F1 (dostęp: 10.09.2019). 
Wykres 1. Wydawcy czasopism regionalno-lokalnych w 2019 roku

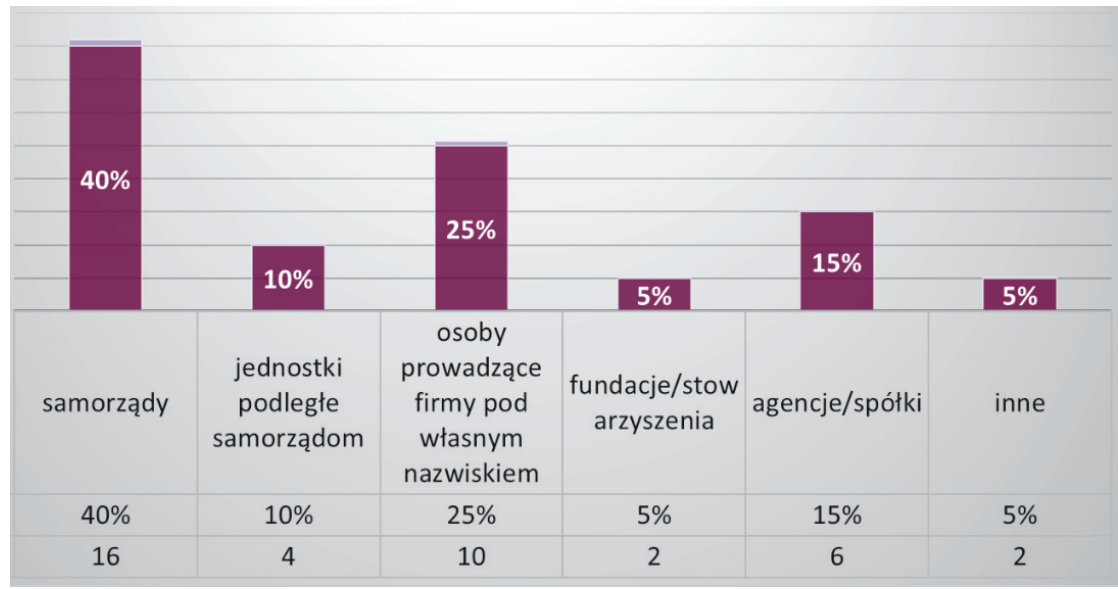

Źródło: opracowanie własne na podstawie na podstawie katalogów BN.

osób prowadzących firmy pod własnym nazwiskiem (Czernichów, Reda, Gliwice, Rawicz, Michałowo, Włoszczowa, Szydłowiec, Gryfino, Wołów), 1 do fundacji (Siedlisko), 1 do stowarzyszenia (Kraków), 6 do różnych agencji, spółek (Żary, Bydgoszcz, Opole, Kluczbork, Kamienna Góra, Kiełczów), 1 jest tygodnikiem radiowym (Września). Przy dwóch tytułach pojawiło się określenie „wydawca nieznany", ale po weryfikacji udało się ustalić, że jeden z nich należy do prywatnego przedsiębiorcy (Środa Śląska) ${ }^{34}$, drugiego nigdzie poza bazą BN nie odnotowano (Rychtal).

9 spośród 40 zarejestrowanych w 2019 roku czasopism regionalno-lokalnych zastąpiło dotychczasowe bądź - stanowiąc ich kontynuację - zmieniło tytuł. $5 \mathrm{z}$ nich to wydawnictwa samorządowe, 4 - inne. Analizując tylko rok 2019, można zauważyć równowagę między czasopismami samorządowymi i pozostałymi. Nie ma też reguły, że wydawnictwa samorządowe adresowane są do małych społeczności, głównie w gminach, a inni wydawcy podejmują działalność w większych ośrodkach. Rozkład według województw już nie jest taki równomierny (wykres 2).

Najwięcej czasopism, po 6, przypada na województwa dolnośląskie i małopolskie, po 4 na kujawsko-pomorskie i wielkopolskie, po 3 na mazowieckie, opolskie i podlaskie. Po 2 nowe tytuły odnotowano w województwach lubelskim, pomorskim, śląskim i świętokrzyskim. W województwach warmińsko-mazurskim i podkarpackim nie zarejestrowano żadnych nowych czasopism, a w województwach lubuskim, łódzkim i zachodniopomorskim po 1.

${ }^{34}$ Zob. http://www.emka.news/bezplatna-gazeta-lokalna (dostęp: 10.09.2019). 
Wykres 2. Nowe czasopisma regionalno-lokalne w 2019 roku w poszczególnych województwach

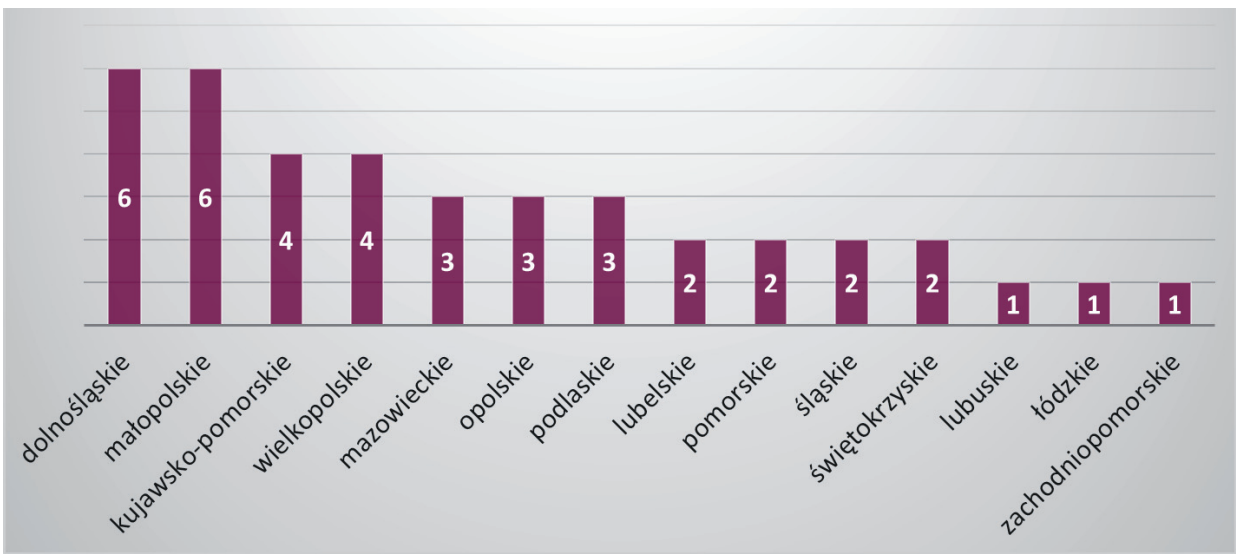

Źródło: opracowanie własne na podstawie katalogów BN.

\section{Wnioski}

Oczywiste jest, że media lokalne odgrywają bardzo istotną rolę w swoich środowiskach. Szczególna rola w procesie komunikacji nadal przypada prasie. W gminach i powiatach ciągle przybywa nowych tytułów, mimo spadku zainteresowania prasą drukowaną w skali globalnej. Jak wszystkie media, prasa lokalna podlega też przemianom, co potwierdza jej ewolucja, pokazana w artykule. Dotychczasowe przeobrażenia wynikały z szeroko rozumianych uwarunkowań rynkowych, rozwoju technologicznego, ale też zmian administracyjnych w kraju. Pragnieniem jest, aby lokalne periodyki nie były zależne od polityki. Przytoczone przykłady zaangażowania różnych gremiów w działania mające na celu wprowadzenie zmian w ukształtowany w latach dziewięćdziesiątych XX wieku system prasowy w Polsce, każą się zastanowić, czy rzeczywiście tak jest. Nie można zakładać, że sytuacja zastana jest idealna i nie należy jej zmieniać. Dążenie do zmian powinno jednak mieć wyraźne uzasadnienie.

W wypadku prasy samorządowej wskazuje się na zagrożenie dla korzystania przez członków danej wspólnoty z ich podstawowych praw i wolności. Znamienne jest jednak, że dostrzegają ten problem przede wszystkim wydawcy prywatni. To w ich imieniu występowały: Helsińska Fundacja Praw Człowieka, Rzecznik Praw Obywatelskich i klub poselski Kukiz'15. Wydaje się zatem, że problem pozostaje tylko na poziomie dysponentów prasy. Można mieć zatem wątpliwości, czy celem podejmowanych działań, zmierzających do zmian prawnych, jest dobro odbiorcy czy nadawcy. Gdyby projekt zmian w prawie prasowym został zaakceptowany, byłoby paradoksem zlikwidowanie prasy lokalnej zależnej od samorządów, a pozostawienie bez zmian mediów ogólnokrajowych, finansowanych i w pełni podporządkowanych władzy państwowej. 
Siła mediów lokalnych wynika z bliskości ich nadawców i odbiorców, z reagowania na potrzeby tych ostatnich i zacieśniania więzi w społecznościach lokalnych. Nie da się jej narzucić ani ograniczyć żadnymi paragrafami. Na rynkach lokalnych powinna być konkurencja, z jasno ustalonymi regułami obowiązującymi wszystkie strony. Próby całkowitego wyeliminowania jednej ze stron ustawowymi zapisami są od tego dalekie.

\section{Bibliografia}

Encyklopedia wiedzy o prasie, J. Maślanka (red.), Zakład Narodowy im. Ossolińskich, Wroclaw 1976.

Głowacka D., Ploszka A., Wydawanie gazet przez jednostki samorzadu terytorialnego - wątpliwości konstytucyjne, „Samorząd Terytorialny” 2014, nr 11; https://www.prawo.pl/samo$\mathrm{rzad} / \mathrm{czy}$-samorzady-powinny-wydawac-gazety,99432.html (dostęp: 3.09.2019).

Goban-Klas T., Media i komunikowanie masowe. Teorie i analizy prasy, radia, telewizji i Internetu, Wydawnictwo Naukowe PWN, Warszawa-Kraków 1999.

Jarren O., Kommunale Kommunikation: Eine theoretische und empirische Untersuchung kommunaler Kommunikationsstrukturen unter besonderer Berücksichtigung lokaler und sublokaler Medien, Minerva Publikation, München 1984.

Jaskiernia A., Media masowe $w$ demokratycznych procesach wyborczych. Standardy europejskie i uwarunkowania ich realizacji, Oficyna Wydawnicza Aspra, Warszawa 2008.

Kępa-Mętrak J., Prasa samorządowa w procesie komunikowania władzy ze społeczeństwem, [w:] J. Kowalik, A. Bednarz (red.), XX lat samorządu terytorialnego w Polsce. Doświadczenia - problemy - perspektywy, Wydawnictwo Adam Marszałek, Toruń 2011.

Kępa-Mętrak J., Relacje pomiędzy lokalna prasa prywatna a samorządową na przykładzie województwa świętokrzyskiego, [w:] M. Lipińska (oprac.), Prasa lokalna w budowie społeczeństwa obywatelskiego, Warszawa 2005.

Kieslich G., Lokale Kommunikation: ihr Stellenwert im Zeitgespräch der Gesellschaft, „Publizistik: Vierteljahreshefte für Kommunikationsforschung” 1972, Vol. 17, No. 1.

Kowalczyk R., O mediach lokalnych, regionie i regionalizmie, Silva Rerum, Poznań 2015.

Kowalczyk R., Prasa lokalna w systemie komunikowania społecznego, Instytut Nauk Politycznych i Dziennikarstwa Uniwersytetu im. Adama Mickiewicza, Poznań 2003.

Kurp M., Lokale Medien und kommunale Eliten Partizipatorische Potentiale des Lokaljournalismus bei Printmedien und Hörfunk in Nordrhein-Westfalen, Westdeutscher Verlag, Opladen 1994.

Prasa lokalna w budowie społeczeństwa obywatelskiego, M. Lipińska (oprac.), Warszawa 2005. Ustawa z dnia 5 czerwca 1998 r. o samorządzie powiatowym; Dz.U. $1998 \mathrm{Nr} 91$ poz. 578 z późn. zm. Ustawa z dnia 5 czerwca 1998 r. o samorządzie województwa; Dz.U. 1998 Nr 91 poz. 576 z późn. zm. Ustawa z dnia 8 marca 1990 r. o samorządzie gminnym; Dz.U. 1990 Nr 16 poz. 95 z późn. zm.

\section{Źródta internetowe}

http://gazetylokalne.pl/dwudziestopieciolatkow-pietnastu/ (dostęp: 2.09.2019). http://gazetylokalne.pl/gminy-nie-powinny-wydawac-gazet/ (dostęp: 4.09.2019). http://gazetylokalne.pl/rzecznik-praw-obywatelskich-w-sprawie-prasy-samorzadowej/ (dostęp: 3.09.2019). 
http://gazetylokalne.pl/slyszalam-ze-sprzedales-gazete-niemcom/ (dostęp: 3.09.2019).

http://gazetylokalne.pl/wp-content/uploads/2015/12/Gazety_lokalne_w_Polsce_-_kalendarium_z_obrazkiem_ver1.pdf (dostęp: 10.09.2019).

http://mak.bn.org.pl/cgi-bin/makwww.exe?BM=24\&IM=07\&WI=2019\&NU=01\&CE=10\&M $\mathrm{A} 1=$ rozwi\%F1(dostęp: 10.09.2019).

http://orka.sejm.gov.pl/Druki8ka.nsf/Projekty/8-020-1123-2018/\%24file/8-020-1123-2018.

pdf (dostęp: 10.09.2019).

http://samorzad.pap.pl/depesze/wiadomosci_centralne/164324/ (dostęp: 3.09.2019).

http://www.emka.news/bezplatna-gazeta-lokalna (dostęp: 10.09.2019).

http://www.obserwatorium.org/index.php?option=com_content\&view=article\&id=4817:czy-wydawanie-gazet-samorzdowych-jest-zgodne-z-konstytucj-petycja-do-rpo\&catid=47:a ktualnosciprog\&Itemid=66 (dostęp: 3.09 .2019$)$.

http://wyborcza.pl/1,75398,20064763,rpo-do-szefa-mswia-wladza-lokalna-nie-powinna-wydawac-gazet.html (dostęp: 3.09.2019).

https://siecobywatelska.pl/gminne-gazety-wladzy/ (dostęp: 3.09.2019).

https://www.hfhr.pl/uwagi-hfpc-do-projektu-ustawy-o-zmianie-ustawy-prawo-prasowe-oraz-niektorych-innych-ustaw/ (dostęp: 4.09.2019).

https://www.hfhr.pl/wp-content/uploads/2016/05/petycja_HFPC_gazety_samorzadowe.pdf (dostęp: 3.09.2019).

https://www.money.pl/gospodarka/wiadomosci/artykul/media-w-polsce-do-kogo-nalezy-prasa-,138,0,1988746.html (dostęp: 3.09.2019).

https://www.money.pl/gospodarka/wiadomosci/artykul/media-w-polsce-do-kogo-naleza-gazety-lokalne,217,0,1996761.html (dostęp: 3.09.2019).

https://www.pb.pl/bodnar-o-samorzadowych-gazetach-830808 (dostęp: 3.09.2019).

https://www.portalsamorzadowy.pl/komunikacja-spoleczna/gminy-i-powiaty-nie-powinny-wydawac-prasy-tylko-biuletyny,80542.html (dostęp: 3.09.2019).

https://www.rpo.gov.pl/pl/content/rpo-samorzady-nie-powinny-wydawac-prasy-jedynie-biuletyny-informacyjne (dostęp: 4.09.2019).

https://www.rpo.gov.pl/pl/content/wydawanie-prasy-przez-wladze-samorzadowe-minister-podziela-watpliwosci-rpo (dostęp: 4.09.2019).

https://www.rpo.gov.pl/pl/content/wystapienie-do-ministra-spraw-wewnetrznych-i-administracji-ws-wydawania-prasy-przez-wladze (dostęp: 4.09.2019).

https://www.rpo.gov.pl/pl/content/wystapienie-do-mkidn-oraz-prezesa-uokik-w-sprawie-wydawania-prasy-przez-wladze-samorzadowe (dostęp: 3.04.2019).

https://www.rpo.gov.pl/sites/default/files/Odp\%20MSWiA\%20prasa\%20samorzadowa\%20 02.06.2016.pdf (dostęp: 4.09.2019).

https://www.rpo.gov.pl/sites/default/files/Wyst\%C4\%85pienie\%20do\%20Ministra\%20Kultury\%20 i\%20Dziedzictwa\%20Narodowego\%20w\%20sprawie\%20wydawania\%20prasy\%20przez\%20 w\%C5\%82adze\%20samorz\%C4\%85dowe\%2C\%2006.07.2016.pdf (dostęp: 4.09.2019).

https://www.rpo.gov.pl/sites/default/files/Wyst\%C4\%85pienie\%20do\%20Prezesa $\% 20$ UOKiK\%20w\%20sprawie\%20wydawania\%20prasy\%20przez\%20w\%C5\%82adze\%20 samorz\%C4\%85dowe\%2C\%2006.07.2016.pdf (dostęp: 4.09.2019).

https://www.rpo.gov.pl/sites/default/files/Wyst\%C4\%85pienie\%20RPO\%20do\%20

MKiDN\%20w\%20sprawie\%20wydawania\%20prasy\%20przez\%20w\%C5\%82adze\%20 samorz\%C4\%85du\%20terytorialnego.pdf (dostęp: 4.09.2019).

https://www.rpo.gov.pl/sites/default/files/Wystapienie\%20do\%20Ministra\%20Spraw\%20Wewnętrznych $\% 20 \mathrm{i} \% 20 \mathrm{Administracji} \% 20 \mathrm{ws} \% 20$ wydawania $\% 20$ prasy $\% 20$ przez $\% 20$ wladze\%20samorzadowe\%2009.05.2016.pdf (dostęp: 3.04.2019). 